\title{
Teaching Video NeuroImage: Reflex Facilitation in Lambert-Eaton Myasthenic Syndrome
}

Antonio Edvan Camelo-Filho, MD,* Eduardo de Paula Estephan, MD, PhD, * Carlos Otto Heise, MD, PhD, and Edmar Zanoteli, MD, PhD

Neurology ${ }^{\circledR}$ 2021;97:e1168-e1169. doi:10.1212/WNL.0000000000012180

Figure Neurophysiologic Findings at Abductor Digiti Minimi

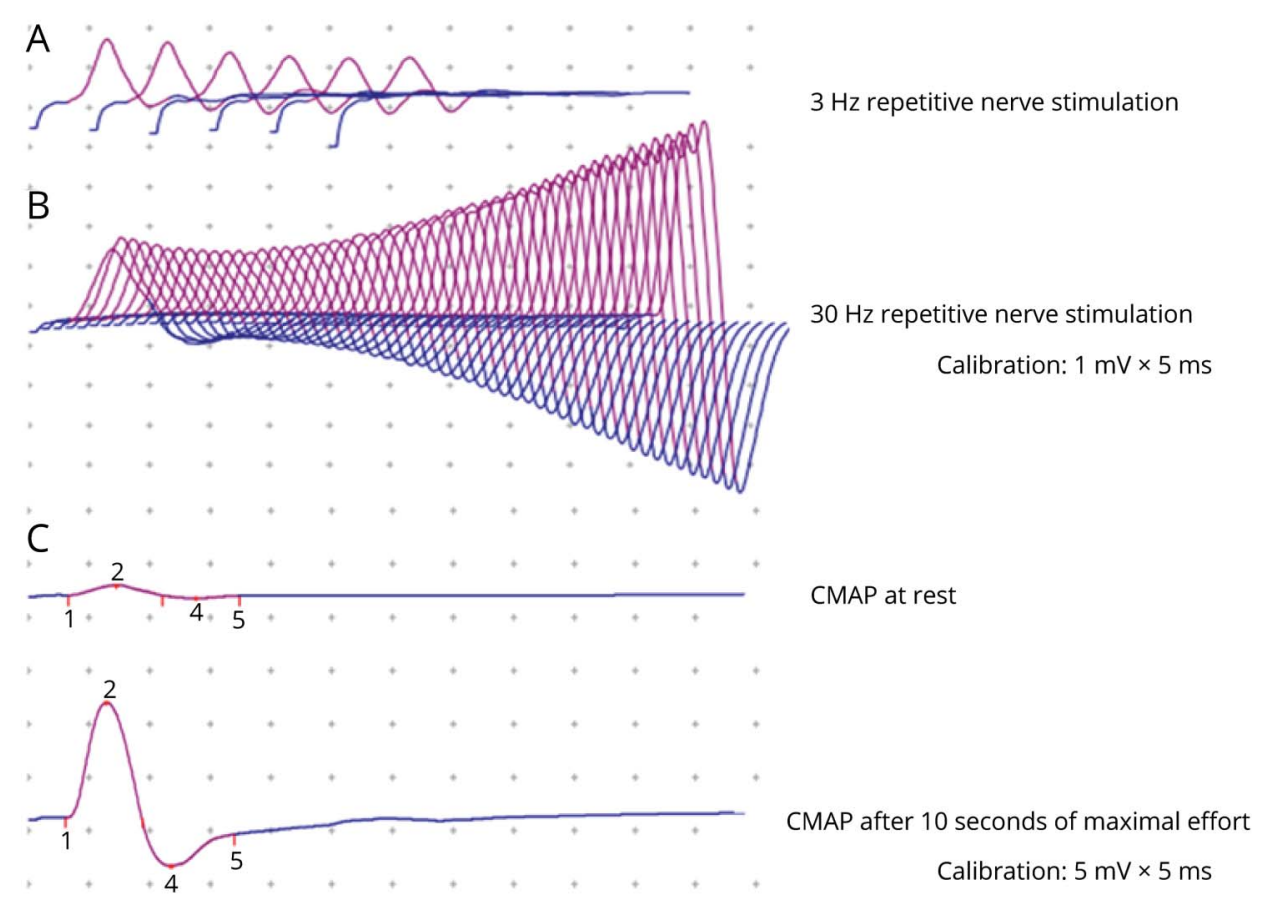

(A) Low-frequency repetitive nerve stimulation shows a decremental response (31.6\%) at $3 \mathrm{~Hz}$. (B) High-frequency repetitive nerve stimulation shows an incremental response $(164 \%)$ at $30 \mathrm{~Hz}$. (C) Compound muscle action potential amplitude increment of $400 \%$ after a 10 -second exercise (postexercise facilitation).

A 41-year-old woman presented with progressive fluctuating lower limb weakness, urinary incontinence, and dry eyes and mouth. Physical examination revealed proximal flaccid tetraparesis (Medical Research Council 4). The patellar reflex was absent, but with postexercise facilitation (video 1). Eyelid and eye movements were normal. Electroneuromyography revealed a presynaptic neuromuscular junction disorder (figure). Antibodies to anti-voltagegated calcium channels were positive. Periodic cancer screening, including whole-body FDGPET, was negative during 2 years of follow-up. These findings were consistent with nonparaneoplastic Lambert-Eaton myasthenic syndrome. ${ }^{1}$ The patient had a good response to IV immunoglobulin. The presence of ascending muscle weakness, autonomic dysfunction, and postexercise facilitation of reflexes should raise suspicion for the diagnosis.
Correspondence

Dr. Camelo-Filho

antonio.edvan@hc.fm.usp.br
MORE ONLINE

\section{Video}

\section{Teaching slides}

links.lww.com/WNL/

B419

\section{Study Funding}

The authors report no targeted funding.

*These authors contributed equally to this work.

From the Department of Neurology (A.E.C.-F., E.d.P.E., C.O.H., E.Z.), Faculdade de Medicina da Universidade de São Paulo; and Department of Neurology (E.d.P.E.), Faculdade de Medicina Santa Marcelina, São Paulo, Brazil.

Go to Neurology.org/N for full disclosures. Funding information and disclosures deemed relevant by the authors, if any, are provided at the end of the article. 


\section{Disclosure}

The authors report no disclosures relevant to the manuscript. Go to Neurology.org/N for full disclosures.

\section{Appendix Authors}

\begin{tabular}{lll}
\hline Name & Location & Contribution \\
\hline $\begin{array}{l}\text { Antonio } \\
\begin{array}{l}\text { Edvan } \\
\text { Camelo-Filho, } \\
\text { MD }\end{array}\end{array}$ & $\begin{array}{l}\text { Universidade de São Paulo, } \\
\text { Brazil }\end{array}$ & $\begin{array}{l}\text { Case report project } \\
\text { (conception, organization, } \\
\text { execution), writing of the first } \\
\text { draft, review and critique }\end{array}$ \\
\hline $\begin{array}{l}\text { Eduardo de } \\
\text { Paula } \\
\text { Estephan, } \\
\text { MD, PhD }\end{array}$ & $\begin{array}{l}\text { Universidade de São Paulo; } \\
\text { Faculdade de Medicina }\end{array}$ & $\begin{array}{l}\text { Case report project } \\
\text { (conception, organization, } \\
\text { execution), writing of the first } \\
\text { draft, review and critique }\end{array}$ \\
\hline
\end{tabular}

Appendix (continued)

\begin{tabular}{lll}
\hline Name & Location & Contribution \\
\hline $\begin{array}{l}\text { Carlos Otto } \\
\text { Heise, MD, } \\
\text { PhD }\end{array}$ & $\begin{array}{l}\text { Universidade de São Paulo, } \\
\text { Brazil }\end{array}$ & $\begin{array}{l}\text { Electrophysiology study } \\
\text { report, writing of the final } \\
\text { draft, final review and } \\
\text { critique }\end{array}$ \\
$\begin{array}{l}\text { Edmar } \\
\text { Zanoteli, MD, } \\
\text { PhD }\end{array}$ & $\begin{array}{l}\text { Universidade de São Paulo, } \\
\text { Brazil }\end{array}$ & $\begin{array}{l}\text { Case report project } \\
\text { (conception, organization, } \\
\text { execution), writing of the } \\
\text { final draft, final review and } \\
\text { critique }\end{array}$ \\
& &
\end{tabular}

\section{Reference}

1. Kesner VG, Oh SJ, Dimachkie MM, Barohn RJ. Lambert-Eaton myasthenic syndrome. Neurol Clin. 2018;36(2):379-394. 


\section{Neurology}

\section{Teaching Video NeuroImage: Reflex Facilitation in Lambert-Eaton Myasthenic Syndrome}

Antonio Edvan Camelo-Filho, Eduardo de Paula Estephan, Carlos Otto Heise, et al. Neurology 2021;97;e1168-e1169 Published Online before print May 26, 2021

DOI 10.1212/WNL.0000000000012180

This information is current as of May 26, 2021

\section{Updated Information \& Services}

References

Subspecialty Collections

Permissions \& Licensing

Reprints including high resolution figures, can be found at: http://n.neurology.org/content/97/11/e1168.full

This article cites 1 articles, 0 of which you can access for free at: http://n.neurology.org/content/97/11/e1168.full\#ref-list-1

This article, along with others on similar topics, appears in the following collection(s):

Clinical neurology examination

http://n.neurology.org/cgi/collection/clinical_neurology_examination EMG

http://n.neurology.org/cgi/collection/emg

Lambert-Eaton syndrome

http://n.neurology.org/cgi/collection/lamberteaton_syndrome Myasthenia

http://n.neurology.org/cgi/collection/myasthenia

Information about reproducing this article in parts (figures,tables) or in its entirety can be found online at:

http://www.neurology.org/about/about_the_journal\#permissions

Information about ordering reprints can be found online:

http://n.neurology.org/subscribers/advertise

Neurology ${ }^{\circledR}$ is the official journal of the American Academy of Neurology. Published continuously since 1951, it is now a weekly with 48 issues per year. Copyright (C 2021 American Academy of Neurology. All rights reserved. Print ISSN: 0028-3878. Online ISSN: 1526-632X.

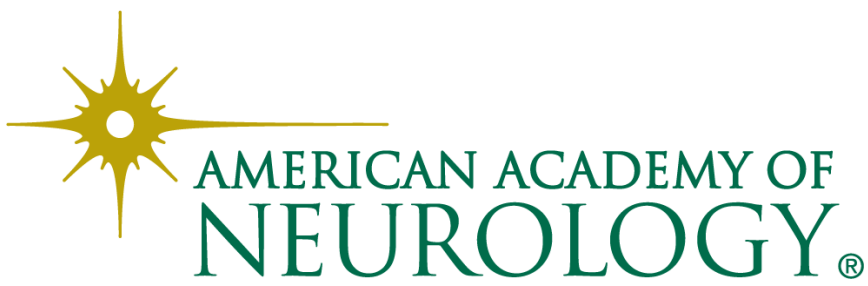

